\begin{tabular}{l|ll} 
J B E & $\mid \begin{array}{ll}\text { JOURNAL OF } \\
\text { BIOLOGY }\end{array}$ & $\begin{array}{l}\text { E-ISSN 2656-3436/ P-ISSN 2615-3947 } \\
\text { IAIN KUDUS } \\
\text { Tersedia online: http://journal.iainkudus.ac.id/index.php/jbe }\end{array}$ \\
\hline
\end{tabular}

\title{
Sikap Peduli Lingkungan Siswa Kota Pekanbaru Melalui Program Adiwiyata Tingkat Nasional
}

\author{
Sri Amnah ${ }^{1}$, Sepita Ferazona ${ }^{2}$ \\ ${ }^{12}$ Program Studi Pendidikan Biologi, Fakultas Keguruan dan Ilmu Pendidikan, Universitas Islam Riau \\ sriamnah@edu.uir.ac.id ${ }^{1}$, sepitabio@edu.uir.ac.id ${ }^{2}$
}

\begin{abstract}
ABSTRAK
Penelitian ini dilakukan dengan tujuan untuk mendapatkan gambaran tentang sikap kepedulian siswa terhadap lingkungan yang ada di sekolah SMPN 13 dan SMPN 34 Pekanbaru yang telah memperoleh penghargaan Adiwiyata tingkat Nasional. Metode yang digunakan pada penelitian ini adalah survei, pengumpulan data dilakukan dengan menggunakan observasi, angket, dan wawancara. Subjek dalam penelitian ini adalah siswa kelas VIII. SMPN 13 dengan sampel 180 siswa,dan SMPN 34 dengan sampel sebanyak 96 siswa. Setiap sekolah memperoleh presentasi yang berbeda. Berdasarkan hasil penelitian dari lembar observasi dan angket, memproleh rata-rata hasil yaitu untuk SMPN 13 Pekanbaru dengan rata-rata observasi $77,92 \%$ dan pada angket siswa dengan rata-rata hasil sebesar 84,93\%. Sementara pada SMPN 34 dengan rata-rata observasi 77,11\% dan pada angket siswa dengan rata-rata hasil sebesar $83,87 \% \%$. Hal ini dapat disimpulkan menunjukkan bahwa SMPN 13 dan SMPN 34 Pekanbaru mempunyai kriteria sangat peduli terhadap lingkungan.
\end{abstract}

\section{Kata Kunci: Sikap Peduli Lingkungan, Program Adiwiyata}

ABSTRACT

This research was conducted with the aim of getting an overview of students' attitudes towards the environment at the 13th Junior High School and the 34th Junior High School in Pekanbaru which have received the National Adiwiyata award. The method used in this study is a survey, data collection is done using observation, questionnaires, and interviews. The subjects in this study were class VIII students. 13th Junior High School with a sample of 180 students, and 34 SMP with a sample of 96 students. Each school gets a different presentation. Based on the results of the research from the observation sheet and questionnaire, obtained the average results, namely for Pekanbaru SMPN 13 with an average observation of $77.92 \%$ and in the student questionnaire with an average yield of $84.93 \%$. While at 34 Public Schools with an average observation of $77.11 \%$ and in student questionnaires with an average yield of $83.87 \% \%$. It can be concluded that the SMP 13 and SMP 34 Pekanbaru have criteria that are very concerned about the environment.

Keywords: Environmental Care Attitude, Adiwiyata Program 


\section{PENDAHULUAN}

Berbicara mengenai pendidikan sangat menarik sekali jika membahas mengenai Pendidikan lingkungan yang diterapkan pada sekolah melalui Program Adiwiyata yang menjadi pendorong bagi sekolah-sekolah yang ada di Indonesia untuk turut serta mengambil bagian dalam perlindungan dan pengelolaan lingkungan. Menurunya kuantitas dan kualitas sumber daya alam (SDA) di Indonesia yang dapat menimbulkan perilaku masyarakat yang ekspolaitatif terhadap pemenuhan kebutuhan SDA, dapat diatasi atau setidaknya dapat dikurangi. Sesuai dengan penelitian yang dilakukan Azmi dan Elfyetti (2017), menyimpulkan lingkungan hidup disertai penanaman sikap peduli lingkungan sekolah dapat meningkatkan sikap peduli lingkungan sekolah sesuai dengan yang diharapkan.

Adiwiyata adalah sebagai tempat yang baik dan ideal dimana dapat diperoleh segala ilmu pengetahuan dan berbagai norma serta etika yang dapat menjadi dasar manusia menuju terciptanya kesejahteraan hidup kita dan menuju kepada cita-cita pembangunan berkelanjutan. Tujuan program Adiwiyata menurut buku panduan Adiwiyata (2012:3) adalah mewujudkan warga sekolah yang bertanggungjawab dalam upaya perlindungan dan pengelolaan lingkungan hidup melalui tata kelola sekolah yang baik untuk mendukung pembangunan berkelanjutan. Adapun indikator program Adiwiyata yang di dalamnya mencakup (1) pengembangan kebijakan sekolah peduli dan berbudaya lingkungan, (2) pengembangan kurikulum berbasis lingkungan, (3) kegiatan lingkungan berbasis, dan (4) pengelolaan saranana pendukung sekolah yang ramah lingkungan. Program sekolah Adiwiyata merupakan bentuk komitmen pemerintah terhadap pengelolaan dan perlindungan lingkungan melalui pendidikan. Kebijakan yang dibuatoleh pemerintah yaitu melalui Peraturan Menteri Lingkungan Hidup Nomor 5 tahun2013 diterjemahkan menjadi program sekolah Adiwiyata.

Biasanya sekolah yang mendapat penghargaan memang benar-benar telah menjaga dan menjadikan sekolah tersebut bersih dan sehat. akan tetapi perlu dilakukan observasi apakah setelah mendapat penghargaan tersebut sekolah masih tetap menjaga kebersihan sekolah dengan baik dan diterapkan oleh seluruh warga sekolah atau hanya beberapa saja dari warga sekolah yang peduli terhadap kebersihan lingkungan sekolah. 
Berdasarkan uraian yang telah dipaparkan, peneliti tertarik untuk melakukan penelitian tentang "Sikap Kepedulian Lingkungan Siswa Kota Pekanbaru Melalui Program Adiwiyata Tingkat Nasional".

Kebersihan merupakan masalah terbesar yang harus diperhatikan terhadap lingkungan khususnya di lingkungan sekolah. Kepedulian siswa-siswi akan kebersihan saat ini semakin menurun, hal ini terbukti dengan banyaknya sampah di lingkungan sekolah. Ketidakpedulian siswa akan kebersihan lingkungan sekolah mengakibatkan lingkungan tidak nyaman dan tidak enak dipandang. Mengatasi masalah yang terjadi perlu adanya sikap kepedulian siswa terhadap lingkungan (Widyaningrum, 2016).

Kementerian Lingkungan Hidup bekerjasama dengan Kementerian Pendidikan dan Kebudayaan mengembangkan program pengelolaan lingkungan yang disebut program Adiwiyata untuk mendukung perlindungan dan pengelelolaan lingkungan hidup di sekolah. Menurut Buku Panduan Adiwiyata (2011) Kata Adiwiyata berasal dari 2 kata Sanskerta ADI dan WIYATA. Kata ADI bermakna besar, baik, ideal atau sempurna. Sedangkan WIYATA bermakna tempat di mana seseorang mendapatkan ilmu pengetahuan, norma dan etika dalam kehidupan sosial. Menurut Buku Panduan Adiwiyata (2012) Adiwiyata adalah sebagai tempat yang baik dan ideal di mana dapat diperoleh segala ilmu pengetahuan dan berbagai norma serta etika yang dapat menjadi dasar manusia menuju terciptanya kesejahteraan hidup kita dan menuju kepada cita-cita pembangunan berkelanjutan.

\section{METODE PENELITIAN}

Penelitian yang dilakukan merupakan penelitian deskriptif kuantitatif dan kualitatif. Deskriptif kuantitatif adalah penelitian usaha sadar dan sistematis untuk memberikan jawaban terhadap suatu masalah dan mendapatkan informasi lebih mendalam dan luas terhadap suatu fenomena dengan menggunakan tahap-tahap penelitian dengan pendekatan kuantitatif (Yusuf, 2014: 62). Metode yang digunakan pada penelitian ini adalah survei, pengumpulan data dilakukan dengan menggunakan observasi, angket, dan wawancara. Subjek dalam penelitian ini adalah siswa kelas VIII. SMPN 13 dengan sampel 180 siswa dan SMPN 34 dengan sampel sebanyak 96 siswa. Data penilaian sikap peduli lingkungan siswa dikumpulkan dengan cara, yaitu dengan menggunakan lembar observasi dan lembar angket. 
Lembar observasi yang digunakan dengan skala Guttman. Skala Guttman ialah skala yang digunakan untuk jawaban yang bersifat jelas (tegas) dan konsisten. Misalnya: yakin tidak yakin; ya - tidak; benar - salah; positif - negatif; pernah - belum pernah; setuju - tidak setuju, dan lain sebagainya. Analisis penghitungan skala Guttman sama seperti pada skala Likert Riduwan dan Sunarto (2010: 24). Lembar observasi digunakan untuk mengamati dan untuk memperoleh data sikap peduli lingkungan. Pada penelitian ini lembar observasi disusun berbentuk turus/tally. Berikut ini kisi-kisi lembar observasi sikap peduli lingkungan.

Menentukan nilai sikap kepedulian lingkungan diambil dari lembaran observasi. Agar peneliti tidak keliru dalam pengelolaan data peneliti menggunakan dua alternatif, yaitu "Ya", dan "Tidak", juga ingin memberikan nilai pada setiap jawaban misalnya nilai 1 untuk jawaban "Ya" dan nilai 0 untuk jawaban "Tidak" (Arikunto, 2014: 285).

Angket adalah sejumlah pertanyaan tertulis yang digunakan untuk memperoleh informasi dari responden dalam arti laporan tentang pribadinya atau hal-hal yang ia ketahui (Arikunto, 2014: 194). Pengambilan data dengan menggunakan angket dilakukan sebanyak 1 kali. Setiap siswa melakukan penilaian terhadap satu siswa lainnya yang menjadi sampel dalam penelitian. Angket diberikan dengan tujuan sebagai data pendukung penilaian sikap kepedulian lingkungan siswa. Hasil yang diperoleh dari angket tersebut dianalisis menggunakan rumus sebagai berikut:

$$
P=\frac{F}{N} \times 100 \%
$$

Keterangan : $\quad \mathrm{P}=$ Angka persentase

$\mathrm{F}=$ Frekensi skor yang diperoleh

$\mathrm{N}=$ Jumlah skor maksimal

Mendeskripsikan sikap kepedulian lingkungan peneliti memodifikasi interval kriteria tingkat sikap kepedulian lingkungan siswa sesuai dengan skor maksimum. Interval kriteria angket tingkat sikap kepedulian lingkungan siswa: 
Tabel 10. Kriteria persentase

\begin{tabular}{c|c|c}
\hline No & Persentase & Kategori \\
\hline 1 & $0 \%-20 \%$ & Tidak Peduli \\
\hline 2 & $21 \%-40 \%$ & Kurang Peduli \\
\hline 3 & $41 \%-60 \%$ & Cukup Peduli \\
\hline 4 & $61 \%-80 \%$ & Peduli \\
\hline 5 & $81 \%-100 \%$ & Sangat Peduli \\
\hline
\end{tabular}

Sumber: Dimodifikasi dari Riduwan (2015: 41 )

\section{HASIL DAN PEMBAHASAN}

Kegiatan lingkungan bersifat partisipasif dilaksanakan sesuai dengan standar sekolah Adiwiyata yang telah ditentukan oleh Kementerian Lingkungan Hidup dan Kementerian Pendidikan. Kegiatan ekrtkurikuler yang dilakukan sekolah salah satunya aksi lingkungan hidup sesusai dengan panduan adiwiyata Adiwiyata $(2012,15)$ bahwa salah satu standar kegiatan lingkungan berbasis partisipatif adalah mengkuti kegiatan aksi yang dilakukan oleh pihak luar hal ini dilakukan oleh sekolah dengan memperingati hari-hari peringatan lingkungan hidup. Untuk mengetahui sikap kepedulian siswa terhadap lingkungan di SMPN 13 dan SMPN 34 Pekanbaru dapat dilihat pada Tabel 1dan Tabel 2 dibawah ini:

Tabel 1. Sikap Kepedulian Lingkungan Siswa SMPN 13 Pekanbaru

\begin{tabular}{clcccc}
\hline No & \multicolumn{1}{c}{ Indikator } & \multicolumn{2}{c}{ Observasi } & \multicolumn{2}{c}{ Angket } \\
\cline { 2 - 5 } & $\mathbf{( \% )}$ & Kategori & $\mathbf{( \% )}$ & Kategori \\
\hline 1. & $\begin{array}{l}\text { Selalu menjaga kelestarian } \\
\text { lingkungan }\end{array}$ & $96,25 \%$ & $\begin{array}{l}\text { Sangat } \\
\text { Peduli }\end{array}$ & $86,1 \%$ & $\begin{array}{l}\text { Sangat } \\
\text { Peduli }\end{array}$ \\
\hline 2. & $\begin{array}{l}\text { Mencintai kerapian dan kebersihan } \\
\text { lingkungan }\end{array}$ & $94,16 \%$ & $\begin{array}{l}\text { Sangat } \\
\text { Peduli }\end{array}$ & $88,37 \%$ & $\begin{array}{l}\text { Sangat } \\
\text { Peduli }\end{array}$ \\
\hline 3. & $\begin{array}{l}\text { Bijaksana dalam menggunakan } \\
\text { SDA }\end{array}$ & $62,98 \%$ & Peduli & $84,35 \%$ & $\begin{array}{l}\text { Sangat } \\
\text { Peduli }\end{array}$ \\
\hline 4. & Mendukung penghijauan & $48,05 \%$ & $\begin{array}{l}\text { Cukup } \\
\text { Peduli }\end{array}$ & $81,11 \%$ & $\begin{array}{l}\text { Sangat } \\
\text { Peduli }\end{array}$ \\
\hline 5. & $\begin{array}{l}\text { Kegiatan lingkungan berbasis } \\
\text { partisipatif }\end{array}$ & $88,20 \%$ & $\begin{array}{l}\text { Sangat } \\
\text { Peduli }\end{array}$ & $84,72 \%$ & $\begin{array}{l}\text { Sangat } \\
\text { Peduli }\end{array}$ \\
\hline & Total & $\mathbf{3 8 9 , 6 4}$ & & $\mathbf{4 2 4 , 6 5}$ & $\begin{array}{l}\text { Sangat } \\
\text { Peduli }\end{array}$ \\
\cline { 2 - 3 } & Rata-rata & $\mathbf{7 7 , 9 2 \%}$ & Peduli & $\mathbf{8 4 , 9 3 \%}$ & \\
\hline
\end{tabular}

Berdasarkan tabel diatas dapat dilihat bahwa hasil Sikap Kepedulian Lingkungan Siswa melalui observasi dan angket untuk SMPN 13 Pekanbaru, observasi memperoleh rata-rata persentasi 78,20\% dengan kriteria yaitu peduli dan angket 87,12\% dengan kriteria sangat peduli. presentasi tertinggi terdapat pada indikator 1 yaitu selalu menjaga kelastrian 
lingkungan untuk hasil observasi, sementara untuk angket presentasi tertinggi pada indikator 2 yaitu mencintai kerapian dan kebersihan lingkunganTabel 2. Sikap peduli lingkungan siswa kelas VIII SMPN 34 Pekanbaru

\begin{tabular}{|c|c|c|c|c|c|}
\hline \multirow{2}{*}{ NO } & \multirow{2}{*}{ Indkator } & \multicolumn{2}{|c|}{ Observasi } & \multicolumn{2}{|c|}{ Angket } \\
\hline & & $\%$ & Kategori & $\%$ & kategori \\
\hline 1 & $\begin{array}{l}\text { Selalu menjaga kelestarian } \\
\text { lingkungan. }\end{array}$ & $95,83 \%$ & $\begin{array}{l}\text { Sangat } \\
\text { Peduli }\end{array}$ & $84,85 \%$ & $\begin{array}{l}\text { Sangat } \\
\text { Peduli }\end{array}$ \\
\hline 2 & $\begin{array}{l}\text { Mencintai kerapian dan kebersihan } \\
\text { lingkungan. }\end{array}$ & $95,60 \%$ & $\begin{array}{l}\text { Sangat } \\
\text { Peduli }\end{array}$ & $89,06 \%$ & $\begin{array}{l}\text { Sangat } \\
\text { Peduli }\end{array}$ \\
\hline 3 & $\begin{array}{l}\text { Bijaksana dalam menggunakan } \\
\text { SDA. }\end{array}$ & $65,12 \%$ & Peduli & $81,25 \%$ & $\begin{array}{l}\text { Sangat } \\
\text { Peduli }\end{array}$ \\
\hline 4 & Mendukung penghijauan. & $41,67 \%$ & $\begin{array}{l}\text { Cukup } \\
\text { Peduli }\end{array}$ & $79,64 \%$ & Peduli \\
\hline 5 & $\begin{array}{l}\text { Kegiatan lingkungan berbasis } \\
\text { partisipatif. }\end{array}$ & $87,32 \%$ & $\begin{array}{l}\text { Sangat } \\
\text { Peduli }\end{array}$ & $84,57 \%$ & $\begin{array}{l}\text { Sangat } \\
\text { Peduli }\end{array}$ \\
\hline & JUMLAH & $385,54 \%$ & & $419,37 \%$ & Sangat \\
\hline & RATA-RATA & $77,11 \%$ & teciun & $83.87 \%$ & Peduli \\
\hline
\end{tabular}

Tabel diatas menunjukkan presentasi yang berbeda pada setiap indikator, baik data yang diperoleh melalui observasi maupun data dari angket. presentasi tertinggi dari hasil observasi diperoleh oleh indikator 1 yaitu selalu menjaga kelestarian lingkungan dengan presentasi $95,83 \%$, sementara untuk hasil agket presentasi yang tertinggi yaitu indikator 2 dengan presentasi $89,06 \%$. Indikator 4 hasil observasi di peroleh presentasi cukup peduli, hal ini disebabkan karena kurang adanya pepohonan di sekolah tersebut.

Hasil penelitian yang dilakukan oleh peneliti di SMPN 13 diperoleh data rata-rata presentasi untuk observasi yaitu $77,92 \%$ katagori peduli dan rata-rata dari angket memperoleh rata-rata presentasi 84,93\% katagori sangat peduli dan SMPN 14 Pekanbaru diperoleh data rata-rata presentasi untuk observasi yaitu $77,11 \%$ katagori peduli dan rata-rata dari angket memperoleh rata-rata presentasi 83,87\% katagori sangat peduli .

Hasil wawancara yang dilakukan dengan Kepala Koordinator Adiwiyata didapatkan kepala sekolah dalam menyukseskan Program Adiwiyata adalah pembuatan visi dan misi sekolah yang peduli dan berbudaya lingkungan, seluruh mata pelajaran yang diajarkan oleh semua guru di sekolah mengintegrasikan berwawasan pada kesadaran terhadap pembentukkan lingkungan. 
Penyampaian materi tentang pentingnya pemeliharaan dan pemanfaatan secara baik terhadap lingkungan hidup kepada para siswa dilakukan pengembangan kurikulum. Pengembangan materi ajar oleh guru, model dan metode belajar bervariasi, dilakukan untuk memberikan pemahaman kepada siswa tentang lingkungan hidup yang dikaitkan dengan persoalan lingkungan sehari-hari. Penghematan sumberdaya alam (listrik,air,dan alat tulis kantor). Peningkatan kualitas pelayanan makanan sehat. Pengembangan sistem pengelolaan sampah. Menciptakan kegiatan ekstrakurikuler di bidang lingkungan hidup berbasis partisipatif di sekolah. Mengikuti kegiatan aksi lingkungan hidup. Hal ini di lakukan di Sekolah dengan bimbingan Kapala Sekolah, Guru dan Staf Sekolah serta siswa yang selalu kerjasama untuk menjaga lingkungan sekolah.

Selama waktu dilakukan observasi peneliti melihat siswa membuang sampah pada tempatnya yang sesuai dengan jenis sampah karena tong sampah setiap kelas ada tiga, siswa juga memilah sampah untuk didaur ulang kembali karena untuk daur ulang ada mata peajarannya yaitu prakarya.

Hasil penelitian yang dilakukan oleh peneliti sesuai dengan penelitian yang dilakukan sebelumnya oleh Fridantara (2015) yang menyimpulkan pelaksanaan Program Adiwiyata di SMAN 2 Klaten sudah sesuai dengan buku Panduan Adiwiyata. Hal tersebut ditandai dengan kebijakan merubah visi misi yang memuat nilai lingkungan hidup, integrasi materi wawasan lingkungan dalam mata pelajaran baik dalam mata pelajaran dan kegiatan ekstrakurikuler, melaksanakan kegiatan aksi lingkungan baik yang disenggarakan oleh sekolah maupun yang diselenggarakan oleh pihak luar, dan pemanfaatan sarana greenhouse dan rumah kompos untuk pembelajaran. Namun pelaksanaan program tidak lepas dari kendala. Penelitian yang dilakukan oleh Amalia (2015) Menyimpulkan bahwa upaya pelestarian lingkungan hidup melalui Program Adiwiyata yang dilaksanakan di SMP Negeri 2 Depok sangat efektif dimanfaatkan untuk sumber belajar bagi peserta didik. Sumber belajar yang digunakan dengan metode praktik lapangan. Jadi peserta didik langsung praktik ke lapangan sesuai dengan materi yang berkaitan dengan lingkungan.

Penelitian yang dilakukan oleh Muranti, Nurmelani dan Hastuti (2015), menyimpulkan hipotesis menyatakan bahwa sikap siswa terhadap kepedulian lingkungan di SMPN 3 Banjarmasin tahun ajaran 2014/2015 dikatakan sebagian besar perduli. Penelitian yang 
dilakukan di SMPN 3 Banjarmasin mengenai sikap siswa terhadap kepedulian lingkungan menunjukkan bahwa sepenuhnya siswa peduli pada lingkungan dengan jumlah siswa 207 dan persentase sebesar $83,81 \%$.

Hasil penelitian ini sesuai dengan penelitian sebelumnya. Berdasarkan hasil penelitian yang dilakukan oleh Sumarlin, Rachmawati dan Suratman (2013) dari penelitian tersebut dapat disimpulkan bahwa tingkat kepedulian siswa terhadap pengelolaan lingkungan sekolah melalui program Adiwiyata di sekolah yang terletak di Kota Lama (SMPN 2 Kendari) tergolong sedang dengan persentase 81\% dan di Kota Baru (SMPN 17 Kendari) tergolong tinggi dengan persentase $86,1 \%$, adanya perbedaan kepedulian ini dipengaruh persepsi siswa terhadap program Adiwiyata, ini arti nya semakin tinggi persepsi siswa terhadap pengelolaan lingkungan sekolah maka kepedulian siswa terhadap pengelolaan lingkungan sekolah terhadap program Adiwiyata semakin tinggi.

\section{SIMPULAN}

Penelitian yang dilakukan oleh Wahyuningtiyas, Harsastro dan Supratiwi (2013) yang dapat diambil kesimpulan bahwa program Adiwiyata yang dilaksanakan sudah sesuai dengan Visi dan Misi SMAN 11 Semarang, yaitu untuk mewujudkan sekolah yang peduli dan berbudaya lingkungan. Dari Visi dan Misi tersebut diperlukan beberapa kebijakan sekolah yang mendukung dilaksanakannya kegiatan-kegiatan pendidikan lingkungan hidup oleh semua warga sekolah sesuai dengan prinsip-prinsip dasar program Adiwiyata yaitu partisipatif dan berkelanjutan. Berkaitan dengan hal tersebut sekolah sudah mengembangkan pembelajaran lingkungan hidup dengan baik dimana warga sekolah perlu dilibatkan dalam berbagai aktivitas pembelajaran lingkungan hidup. Kegiatan-kegiatan yang dapat dilakukan adalah dengan menciptakan kegiatan ekstrakurikuler/kurikuler dibidang lingkungan hidup berbasis partisipatif sekolah, serta mengikuti kegiatan aksi lingkungan hidup yang dilakukan oleh pihak luar. 


\section{DAFTAR PUSTAKA}

Aini, M.H., F. Rachmadiarti., \& M.J. Prastiwi. 2014. Penguasaan Konsep Lingkungan Dan Sikap Peduli Lingkungan Siswa SMA Adiwiyata Mandiri di Kabupaten Mojokerto, Online Vol.3, No.3, Agustus 2014. Diambil dari http://jurnalmahasiswa.unesa.ac.id/article/12652/34/article.pdf. (Diakses 20 februari 2017).

Amalia, N. H. 2015. Upaya Pelestarian Lingkungan hidup Melalui Program Adiwiyata sebagai Sumber Belajar bagi Peserta Didik. Jakarta: Skripsi Program Studi IPS Tarbiya.

Diambilhttp://repository.uinjkt.ac.id/dspace/bitstream/123456789/29231/1/SKRIPSI \%20WATERMARK.).(Diakses 20 Februari 2017).

Aprilia, N. 2016. Evaluasi Pengembangan Kegiatan Berbasis Partisipatif Pada Program Adiwiyata Di Smp Muhammadiyah Yogyakarta. Diambil dari. Jurnal Pendidikan Vol.3.No.2 Tahun 2016. https://www.researchgate.net/profile/Nani_Aprilia/publication/310954296_EVALU ASI_PENGEMBANGAN_KEGIATAN_BERBASIS_PARTISIPATIF_PADA_PR OGRAM_ADIWIYATA_DI_SMP_MUHAMMADIYAH_YOGYAKARTA_Evalu ation_Of_Development_Activities_Based_Participatory_On_Adiwiyata_Program_I

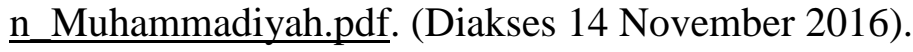

Arikunto, S. 2014. Prosedur Penelitian Suatu Pendekatan Praktik. Jakarta: Rineka Cipta.

Aprianto, K. 2016. Ini Daftar Sekolah Adiwiyata di Pekanbaru 2012-2016. Gilang NewsDiambil http://gilangnews.com/news/detail/1309/ini-daftar-sekolah-sekolahadiwiyata-di-pekanbaru-2012-2016. 14 November 2016.(Diakses 15 Mei 2017).

Azmi, F., Elfyetti.Analisis Sikap Peduli Lingkungan Siswa Melalui Program Adiwiyata di SMA Negeri 1 Medan.Jurnal Geografi Vol 9 No.2 (125-132). Diambil dari http://jurnal.unimed.ac.id/2012/index.php/geo/article/download/6901/6052(Di akses 1 November 2017).

Badan Pusat Statistik (BPS). 2013. Indikator Perilaku Peduli Lingkungan Hidup 2013. Jakarta: BPS

Depdiknas, 2009. Peraturan Menteri Negara Lingkungan Hidup No 2 Tahun 2009 Tentang Pedoman Pelaksanaan Program Adiwiyata.

Depdiknas, 2009. Peraturan Menteri Negara Lingkungan hidup No 32 Tahun 2009 tentang Perlindungan Lingkungan hidup.

Depdiknas, 2013. Peraturan Menteri Negara Lingkungan hidup No 05 Tahun 2013 Tentang Pedoman Pelaksanaan program Adiwiyata.

Febriana, Ibrohim, \& Mahanal. 2016. Potensi Pembelajaran Inkuiri dalam Menumbuhkan Sikap Siswa Terhadap Lingkungan. Fakultas MIPA Universitas Negri Malang. Diambilhttp://pasca.um.ac.id/wp-content/uploads/2017/02/Indri-Febriana-959969.pdf. (Diakses tanggal 2 Februari 2017). 
Fiana, F.J., Daharnis \& M. Ridha. Disiplin Siswa di Sekolah dan Implikasinya dalam Pelayanan Bimbingan dan Konseling. Jurnal Ilmiah Konseling Vol. 2. No. 23. Tahun 2013. Hlm. 26-33. Diambil dari http://download.portalgaruda .org/article.php?article=129361\&val=1533. (Di akses 1 Oktober 2017).

Fridantara, S, A. 2015 "Impementasi Program Adiwiyata di SMA Negeri 2 Klaten”. Diambil dari http://eprints.uny.ac.id/29450/1/Angga\%20Swasdita\%20F_11101241034.pdf. (Diakses tanggal 8 Februaru 2017).

Gunawan, Z. 2016. Pengembangan Program Adiwiyata dalam Mewujudkan Sekolah Peduli dan Berbudaya Lingkungan. Jurnal Pendidikan Vol. 3. No 2 Tahun 2016: Hlm 84. 87. pedagogik. Diambil jurnal.iainuruljadid.ac.id/index.php/pedagogik/article/ view/15/18. (Diakses tanggal 1 Februari 2017).

Handayani, A. 2013. Peningkatan Sikap Peduli Lingkungan melalui Implementasi Pendekatan Sains Teknologi Masyarakat (STM) dalam Pembelajaran IPA Kelas IV.1 di SDN Keputaran. Yogyakarta: Skripsi Program Studi Pendidikan Guru Sekolah Dasar FKIP Yogyakarta. Diambilpedagogik. jurnal. iainuruljadid.ac.id/index.php/pedagogik/article/view/15/18. (Diakses 22 Februari 2017).

Iswari, R. I. \& S.W. Utomo. 2017. Evaluasi Penerapan Program Adiwiyata Untuk Membentuk Perilaku Peduli Lingkungan di Kalangan Siswa (Kasus: SMA) Negeri 9 Tangerang Selatan dan MA Negeri 1 Serpong). Jurnal Ilmu Lingkungan Vol.15 Issue 1 (2017) : $\quad 35-41 . \quad$ Diambil dari http://ejournal.undip.ac.id/index.php/ilmulingkungan/article/download/13012/ PDF. (Di akses 12 Oktober 2017).

Kemendikbud, 2012. Panduan Adiwiyata Sekolah Peduli dan Berbudaya Lingkungan. Kerjasama Kementerian Lingkungan Hidup dengan kementerian Pendidikan dan Kebudayaan.

Kemendikbud, 2011. Panduan Adiwiyata Sekolah Peduli dan Berbudaya Lingkungan. Kerjasama Kementerian Lingkungan Hidup dengan kementerian Pendidikan dan Kebudayaan.

Kunandar, 2014. Penilaian Autentik (Penilaian Hasil Belajar Peserta Didik Berdasarkan Kurikulum 2013).Edisi Revisi. Jakarta: Rajawali Pers.

Muranti, H, Normelani, \& K.P. Hastuti. 2015 Sikap siswa Terhadap Kepedulian Lngkungan \begin{tabular}{llllll} 
Di & SMPN & 3 & Banjarmasin & Tahun & Ajaran \\
\hline
\end{tabular} Diambilhttp://ppjp.unlam.ac.id/journal/index.php/jpg/article/view/1425. (DIakses 13 Oktober 2017)

Riduwan, 2015. Dasar-Dasar Statistika. Bandung: Alfabeta.

Riduwan \& Sunarto. 2010. Pengantar Statistik. Bandung: Afabeta.

Sudijono, A. 2012. Pengantar Statistik Pendidikan. Jakarta: Rajawali Pers. 
Sukmadinata, S. N. 2011. Metode Penelitian Pendidikan. Bandung: PT Remaja Rosdakarya.

Sumarlin, R., Rachmawati., \& Suratman. 2013. Persepsi dan Kepedulian Siswa terhadap Pengelolaan Lingkungan Sekolah melalui Program Adiwiyata, Online Vol.27. No. 1. Maret 2013. Diambil dari https://jurnal.ugm.ac.id/mgi/article/view/13447. (Diakses 20 februari 2017).

Wahyuningtyas, D., P. Harsastro., \& Supratiwi. 2013. Evaluasi Program Adiwiyata Di SMAN 11 Semarang. Diambil dari http://download.portalgaruda. org/article.php?article=72809\&val=4924. (Diakses tanggal 5 Februari 2017).

Widyaningrum, T. 2016. Tingkat Kepedulian Siswa Terhadap Lingkungan di SMA Negri 5 Kediri. Diambil dari https://simki.unpkediri.ac.id/mahasiswa/file_artikel/2016/11.1.01.06.0087.pdf. (Diakses tanggal 5 Februari 2017).

Yusuf, M. 2014. Metode Penelitian (Kuantitatif, Kualitatif \& Penelitian Gabungan). Jakarta: PT Fajar Inter Pratama Mandiri. 